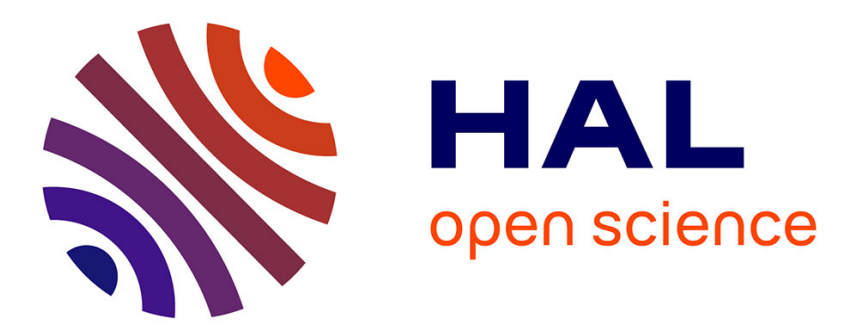

\title{
Experimental study of compression after impact of asymmetrically tapered composite laminate
}

Hakim Abdulhamid, Christophe Bouvet, Laurent Michel, Jacky Aboissière, Clément Minot

\section{- To cite this version:}

Hakim Abdulhamid, Christophe Bouvet, Laurent Michel, Jacky Aboissière, Clément Minot. Experimental study of compression after impact of asymmetrically tapered composite laminate. Composite Structures, 2016, vol. 149, pp. 292-303. 10.1016/j.compstruct.2016.04.015 . hal-01360642

\section{HAL Id: hal-01360642 \\ https://hal.science/hal-01360642}

Submitted on 6 Sep 2016

HAL is a multi-disciplinary open access archive for the deposit and dissemination of scientific research documents, whether they are published or not. The documents may come from teaching and research institutions in France or abroad, or from public or private research centers.
L'archive ouverte pluridisciplinaire HAL, est destinée au dépôt et à la diffusion de documents scientifiques de niveau recherche, publiés ou non, émanant des établissements d'enseignement et de recherche français ou étrangers, des laboratoires publics ou privés. 


\section{Open Archive TOULOUSE Archive Ouverte (OATAO)}

OATAO is an open access repository that collects the work of Toulouse researchers and makes it freely available over the web where possible.

This is an author-deposited version published in: http://oatao.univ-toulouse.fr/ Eprints ID: 15957

To link to this article: DOI: $10.1016 / j . c o m p s t r u c t .2016 .04 .015$

URL: http://dx.doi.org/10.1016/j.compstruct.2016.04.015

To cite this version: Abdulhamid, Hakim and Bouvet, Christophe and Michel, Laurent and Aboissière, Jacky and Minot, Clément Experimental study of compression after impact of asymmetrically tapered composite laminate. (2016) Composite Structures, vol. 149. pp. 292-303. ISSN 0263-8223

Any correspondence concerning this service should be sent to the repository administrator: staff-oatao@listes-diff.inp-toulouse.fr 


\title{
Experimental study of compression after impact of asymmetrically tapered composite laminate
}

\author{
Hakim Abdulhamid $^{\mathrm{a}}$, Christophe Bouvet ${ }^{\mathrm{a}, *}$, Laurent Michel $^{\mathrm{a}}$, Jacky Aboissière ${ }^{\mathrm{b}}$, Clément Minot ${ }^{\mathrm{b}}$ \\ ${ }^{a}$ Université de Toulouse; INSA, UPS, EMAC, ISAE; ICA (Institut Clément Ader), France \\ ${ }^{\mathrm{b}}$ Sogeti High Tech, Aéropark, 3 chemin de Laporte, 31300 Toulouse, France
}

Keywords:

Composite

Ply drop-off

Impact

Compression after impact

Damage tolerance

\begin{abstract}
A B S T R A C T
This paper presents an experimental study of CAI (compression after impact) of tapered composite laminate. Two types of layup with thickness changing from $4 \mathrm{~mm}$ to $6 \mathrm{~mm}$ are considered. A new CAI testing rig, suitable for the specimens and a brief description of impact damage are presented first. Then, the behavior of impacted specimens under compressive loading is discussed along with the effects of ply drop-off parameters (taper angle, ply drop-off disposition and configuration) and impact point location on the failure mechanism. Finally, the residual strength in CAI of tapered laminates is compared with equivalent flat laminates. The results show that compressive behavior of the specimens is mostly governed by a coupling between compression and bending, generated by the discontinuity of the neutral axis in the tapered region. Despite this difference of behavior with flat laminates, the presence of ply drop-off has little effect on the residual strength in CAI.
\end{abstract}

\section{Introduction}

Low velocity/low energy impact on composite structure is known to create a large expanse of damage inside the laminate while leaving a barely visible indent on its surface. Such damage reduces the residual strength after impact and especially, its compressive strength $[1,2]$. In aeronautics, this loss of strength obliges the designer to account for damage tolerance and to use only a portion of the potential of the material. Therefore, understanding the mechanisms that lead to premature failure of the structure is important in order to improve the residual strength of the laminate.

Today, extensive experimental studies of CAI on flat laminates are available in the literature. Apart from measuring the residual strength, authors investigated the influences of many parameters like the resin $[3,4]$, the staking sequence $[5,6]$ and the transverse reinforcement [7-9]. Others focus on the study of failure mechanisms during CAI and identified three major mechanisms: buckling, propagation of delamination and fiber failure. The majority of authors agree that buckling or local buckling leads to premature failure of the laminates [5,10-13]. In fact, the delamination created during impact divides the plate into multiple sub-laminates. Since

* Corresponding author at: ISAE (Institut Supérieur de l'Aéronautique et de l'Espace), 10, avenue Edouard Belin, BP 54032, 31055 Toulouse Cedex 4, France. E-mail address: christophe.bouvet@isae.fr (C. Bouvet). the buckling strength of a sub-laminate is lower compared to the initial plate, buckling or local-buckling is likely to happen during CAI. In some cases $[4,9,14]$, the buckling induces some propagation of delamination before the plate total failure. However, the delamination does not necessary lead to total collapse of the specimen since its initial propagation does not reach the lateral edges. Furthermore, some authors [15-17] observed some propagation of compressive fiber failure going from the impact area. This crack propagation can be induced by buckling or local stress concentration and in some cases leads to the final collapse of the specimen. In summary, failure in CAI of flat laminate is due to multiple mechanisms and some coupling can be involved between them. Those different studies highlighted the complexity of the phenomena, yet, they have permitted a reasonable understanding of the CAI behavior of flat laminates.

Regarding the tapered laminates, according to the authors' knowledge, there is no related detailed study of their CAI. The majority of authors deal with their static [18-20] or fatigue $[21,22]$ strength. For example, by means of Moiré interferometry, Xing et al. [18] studied the failure mechanism at the toe and the knee of the resin pocket under tensile and compressive loadings. Steeves and Fleck [19] investigated the influences of interlaminar delamination and fiber micro-buckling on the compression strength of tapered laminates. Weiss et al. [22] studied the influence of ply drop-off location with regards to the initiation of delamination in fatigue. Few authors performed impact studies of 
tapered laminates. Greenhald et al. [23] conducted a detailed comparison of impact study at the stringer foot and bay of a stiffened panel. It is found that the ply drop-off represented by the stringer foot modifies the local bending stiffness of the laminate. The propagation of damage is less important at the stringer foot compared to the damage created by an impact at the bay. Kairouz and Ball [24] investigated the impact performance of non-crimp fabric composite material with an internally dropped-off ply. They recorded a loss of $20 \%$ of the damage initiation threshold force compared to plain laminates.

The effects of ply drop-off on the CAI strength and failure mechanisms have not been studied and need to be investigated since those particular areas can also be subjected to impact in an aircraft structure.

Impact and CAI strength are material and structural related properties. For this reason, the specimen size and tests boundary conditions influence the results. The majority of available studies follow industrial standards like (BSS7260 [25] or AITM1-0010 [26]). The standards are quite similar and were defined to predict the CAI strength of a monolithic flat panel. It is only recently that international standards (ASTM7136 and ASTM7137 [27,28]) are available for the tests. However, there is still no standard for the study of impact and CAI of asymmetrically tapered composite panel. Therefore, new dimensions of specimens and boundary conditions need to be defined.

This study continues an ongoing research on the impact damage tolerance of tapered laminates. The first part of it, characterizing the impact damage is available in [29]. This paper is devoted to the analysis of the behavior and residual strength under compressive loading of impacted specimens with ply drop-off. After the presentation of specimens features, a new boundary condition for CAI test of asymmetrically tapered laminate is introduced and validated. Then, the behavior in CAI of tapered specimens is described considering the effect of impact point location and face. Next, the failure mechanism in CAI is studied. And finally, the residual strength in compression of tapered laminates is compared with that of the flat ones.

\section{Experimental Setup}

\subsection{Specimens and tests boundary conditions}

Two types of layup, A and B, presented in Table 1 are considered in this study. Both layups have the same thickness range. For A (B) specimen, the thickness of the thick section is $6(6.25) \mathrm{mm}$ and that of the thin section is $4(4) \mathrm{mm}$. The main difference between both layups is in the number of inter-laminar interfaces. For layup $A$, the number is reduced by grouping in pairs the plies of the same orientation. For layup B, plies are more distributed through the thickness, therefore, increasing the number of interfaces compared to $A$. Fig. 1 illustrates the layup of A and B tapered specimens and the ordering of the dropped-off plies in the tapered area. Two versions of $\mathrm{B}\left(\mathrm{B}^{1}\right.$ and $\left.\mathrm{B}^{2}\right)$ are considered by changing the ordering of dropped-off plies. Also for $A$, the dropped-off groups of plies are terminated whether in staggered $\left(A^{\text {st }}\right)$ or simultaneous $\left(A^{\text {si }}\right)$ way. The consistency of the spacing is ensured with a microscopic screw
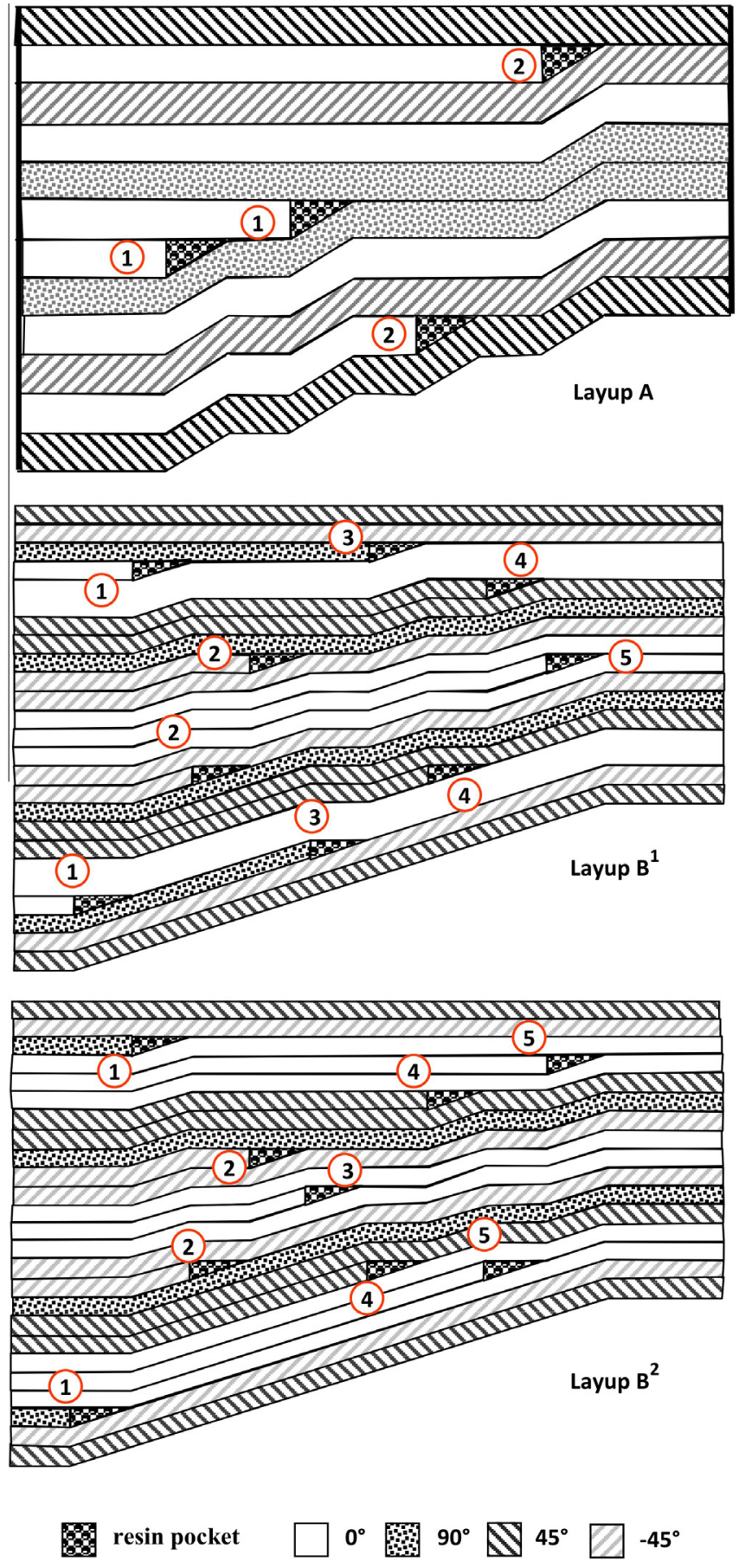

Fig. 1. Layup profile and ply drop-off ordering of layups $A, B^{1}$ and $B^{2}$ specimens.

driven ruler during layup. For $\mathrm{A}^{\mathrm{si}}$ and $\mathrm{B}^{1}$ and $\mathrm{B}^{2}$ layups, two tapering angles are used: a steep one with $1.5 \mathrm{~mm}$ spacing per $0.25 \mathrm{~mm}$ ply thickness and a smooth one with a spacing of $2.5 \mathrm{~mm}$ and a spacing of $1.5 \mathrm{~mm}$ is used in $A^{\text {st }}$ specimens. Additionally, flat

Table 1

Definition of layup of the specimens.

\begin{tabular}{|c|c|c|c|c|c|c|c|c|c|c|c|c|c|}
\hline $\begin{array}{l}\text { Layup A } \\
\text { Termination order }\end{array}$ & $\begin{array}{l}{\left[45_{2}\right.} \\
-\end{array}$ & $\begin{array}{l}\mathrm{O}_{2} \\
\text { 2nd }\end{array}$ & $\begin{array}{l}-45_{2} \\
-\end{array}$ & $\begin{array}{l}0_{2} \\
-\end{array}$ & $\begin{array}{l}90_{2} \\
-\end{array}$ & $\begin{array}{l}\left.0_{2}\right]_{s} \\
1 \mathrm{st}\end{array}$ & & & & & & & \\
\hline Layup B & {$[45$} & -45 & 90 & 0 & 0 & 0 & 45 & 45 & 90 & -45 & -45 & 0 & $\left.0_{1 / 2}\right]_{s}$ \\
\hline Termination order for $\mathrm{B}^{1}$ & - & - & $3 r d$ & $1 \mathrm{st}$ & - & - & 4 th & - & - & 2nd & - & - & 5 th \\
\hline Termination order for $\mathrm{B}^{2}$ & - & - & $1 \mathrm{st}$ & 5 th & - & - & 4th & - & - & 2nd & - & - & 3rd \\
\hline
\end{tabular}


Table 2

Material mechanical properties.

\begin{tabular}{lll}
\hline$\rho$ & Density & $1600 \mathrm{~kg} / \mathrm{m}^{3}$ \\
$E_{l}^{t}$ & Tensile Young's modulus in fiber direction & $130 \mathrm{GPa}$ \\
$E_{l}^{c}$ & Compressive Young's modulus in fiber direction & $100 \mathrm{GPa}$ \\
$E_{t}$ & Transverse Young's modulus & $7.7 \mathrm{GPa}$ \\
$G_{l t}$ & Shear modulus & $4.8 \mathrm{GPa}$ \\
$v_{l t}^{t}$ & Poisson's ratio & 0.33 \\
$\varepsilon_{l}^{t, 0}$ & Tensile failure strain in fiber direction & 0.016 \\
$\varepsilon_{l}^{c, 0}$ & Compressive failure strain in fiber direction & -0.0125 \\
$\sigma_{t}^{r u p t}$ & Transverse tensile strength & $60 \mathrm{MPa}$ \\
$\tau_{l t}^{r \text { rupt }}$ & In-plane shear strength & $110 \mathrm{MPa}$ \\
\hline
\end{tabular}

laminates with respectively the layup of the thin section of $A$ and $B$ are considered as reference, they are respectively named as $A^{P}$ and $B^{P}$. Those flat laminates are only tested at $30 \mathrm{~J}$ energy. All specimens are made of the same material T700GC/M21 (Table 2) available as a unidirectional prepreg tape of $0.25 \mathrm{~mm}$ thick. All specimens are cured in an autoclave at a temperature of $180^{\circ} \mathrm{C}$ and a pressure of 7 bars as suggested by the manufacturer. The detailed nomenclature of the specimens is presented in Table 3.

The impact is performed on the flat face of the specimen at the beginning of the taper region. The tapered face is simply placed above a rectangular window. The interior dimensions of the impact window are $125 \times 75 \mathrm{~mm}^{2}$, similar to that of the standard AITM 1-0010 (Fig. 2a). However, major modification of the conventional
Table 3

Nomenclature of the specimens.

\begin{tabular}{llll}
\hline Layups & Configurations & Step spacing & Nomenclature \\
\hline $\mathrm{A}$ & Staggered & $1.5 \mathrm{~mm}$ & $\mathrm{~A}_{15}^{\mathrm{st}}$ \\
& Simultaneous & $5 \mathrm{~mm}$ & $\mathrm{~A}_{25}^{\mathrm{si}}$ \\
& Flat & $3 \mathrm{~mm}$ & $\mathrm{~A}_{15}^{\mathrm{si}}$ \\
& 1 & - & $\mathrm{A}^{\mathrm{P}}$ \\
$\mathrm{B}$ & $2.5 \mathrm{~mm}$ & $\mathrm{~B}_{25}^{1}$ \\
& 2 & $1.5 \mathrm{~mm}$ & $\mathrm{~B}_{15}^{1}$ \\
& Flat & $2.5 \mathrm{~mm}$ & $\mathrm{~B}_{25}^{2}$ \\
& & $1.5 \mathrm{~mm}$ & $\mathrm{~B}_{15}^{2}$ \\
& & - & $\mathrm{B}^{\mathrm{P}}$ \\
\hline
\end{tabular}

CAI boundary conditions need to be introduced since the discontinuity of neutral axis at the tapered region induces some coupling between compression and bending behaviors. The new boundary conditions are redefined to replicate at the specimen, the behavior of a stiffened panel under compressive loading. The simulation of the response of such panel shows that the coupling induces a blistering of the thin section even below limit load.

Fig. 2b shows the boundary conditions that were chosen for CAI. Both longitudinal ends of the specimen are clamped to resist the bending moment. Tabs are bonded at each end to compensate the thickness variation. For this reason, the length of the specimen is increased to $250 \mathrm{~mm}$ to allocate $50 \mathrm{~mm}$ at each extremity for the tabs. In this way, the area of study remains identical to standard

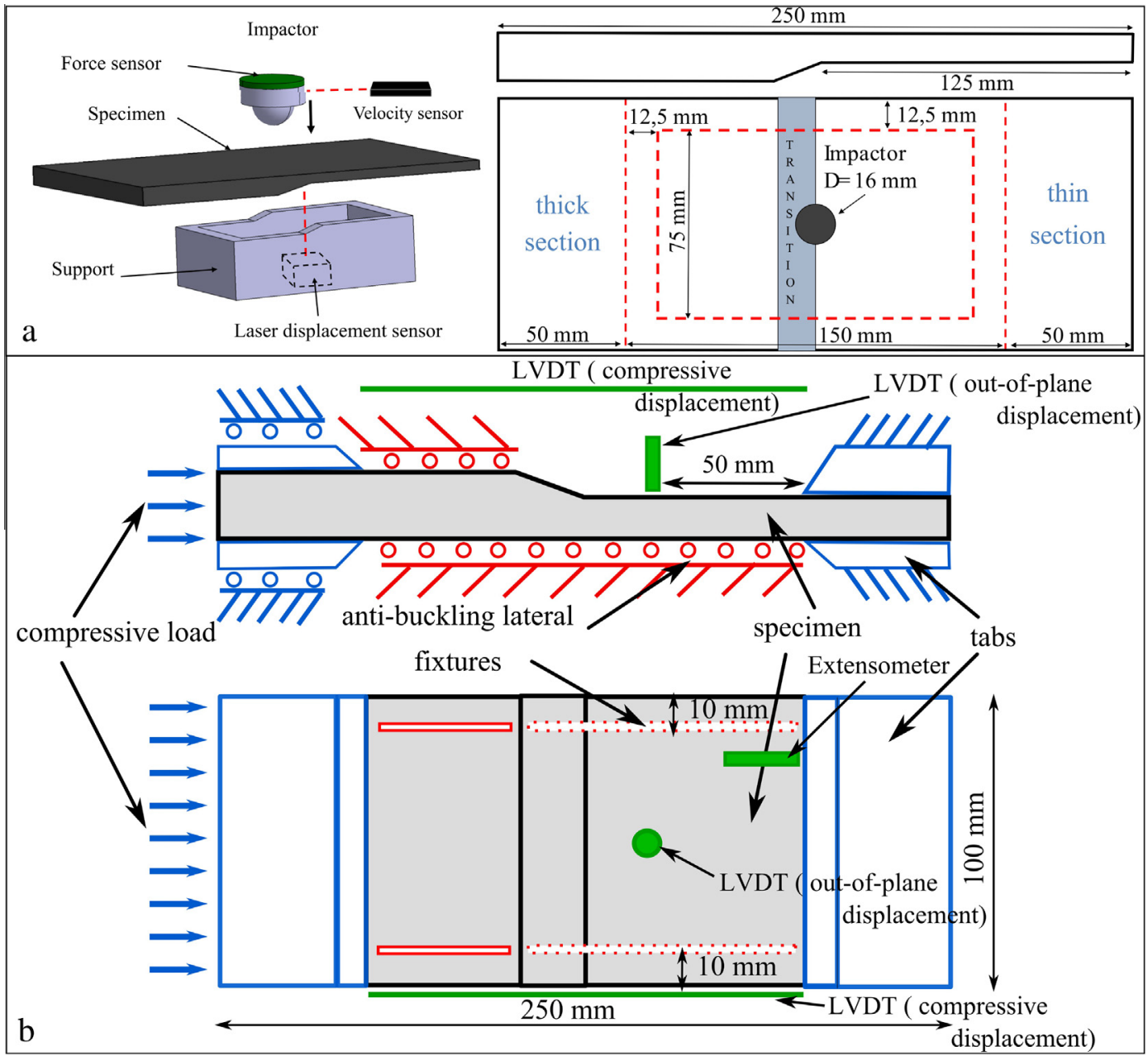

Fig. 2. Tests boundary conditions: (a) impact, (b) CAI. 
CAI specimen $\left(150 \times 100 \mathrm{~mm}^{2}\right)$. Moreover, longitudinal supports are added at $10 \mathrm{~mm}$ from the edges to prevent premature buckling while allowing a blistering of the thin section of the specimen. Note that there are no supports on the tapered face of the thin section. Indeed these supports avoid bending, due to thickness change of the ply drop off, which is representative of a real stiffened panel. A new testing rig, presented in Fig. 3, has been designed and manufactured to satisfy the requirements of the CAI test.

\subsection{Tests procedure}

Impact tests are performed on a drop weight testing rig with a hemispherical shape indentor of $16 \mathrm{~mm}$ diameter. A mass of $4 \mathrm{~kg}$ is attached to the impactor. Three levels of energy are used $10 \mathrm{~J}, 20 \mathrm{~J}$ and $30 \mathrm{~J}$. The contact force is measured with a piezoelectric sensor during the test. Also, the initial impact velocity is obtained from an optical sensor. After impact, delamination is measured with a Cscan system. Before the CAI test, the impacted face is painted in white with a black speckle pattern to monitor the deformation with a stereo-digital image correlation system (Vic3D). Two CCD cameras with $5 \mathrm{Mpx}$ resolutions are used to capture images of the specimens. An extensometer with a gauge length of $25 \mathrm{~mm}$ measures the strain of the thin section far from the impact area and two Linear Variable Differential Transducers (LVDT) measures the compressive and out-of-plane displacements during the test (Fig. 2b).

\section{Validation of CAI boundary conditions}

A compression test of pristine $\mathrm{A}_{15}^{\mathrm{si}}$ specimen is performed to verify the quality of the boundary conditions. The specimen is loaded at a constant rate of $0.02 \mathrm{~mm} / \mathrm{s}$.

The DIC (Digital Image Correlation) data in Fig. 4 gives detailed information regarding the behavior of the specimen. From the beginning of the test, a blistering of the thin section is present. Then, an out-of-plane displacement of the thick section in the direction of the blister is observed as the compression load increases. Fig. 5 shows the evolution of compression force and out-of-plane displacement curves recorded during the test. The displacements are extracted from the DIC and show respectively the displacement at the center of the blister and near to the lower grip. The specimen response is linear until the load reaches $83 \mathrm{kN}$ and failure occurs at $143 \mathrm{kN}$. After a detailed analysis of the data, the origin of the out-of-plane displacement of the thick section is identified to be a small rotation of the lower grip of the testing rig due to the bending of the plate. This induced out-of-plane displacement reaches $0.22 \mathrm{~mm}$ at $100 \mathrm{kN}$ and its amplitude is growing significantly above $120 \mathrm{kN}$.

Apart from this undesired grip displacement, the testing rig is fulfilling its requirements: the specimen can be loaded high enough and the blistering present in the stiffened panel is replicated. The test is considered to be good enough as long as the load does not exceed far from $120 \mathrm{kN}$.

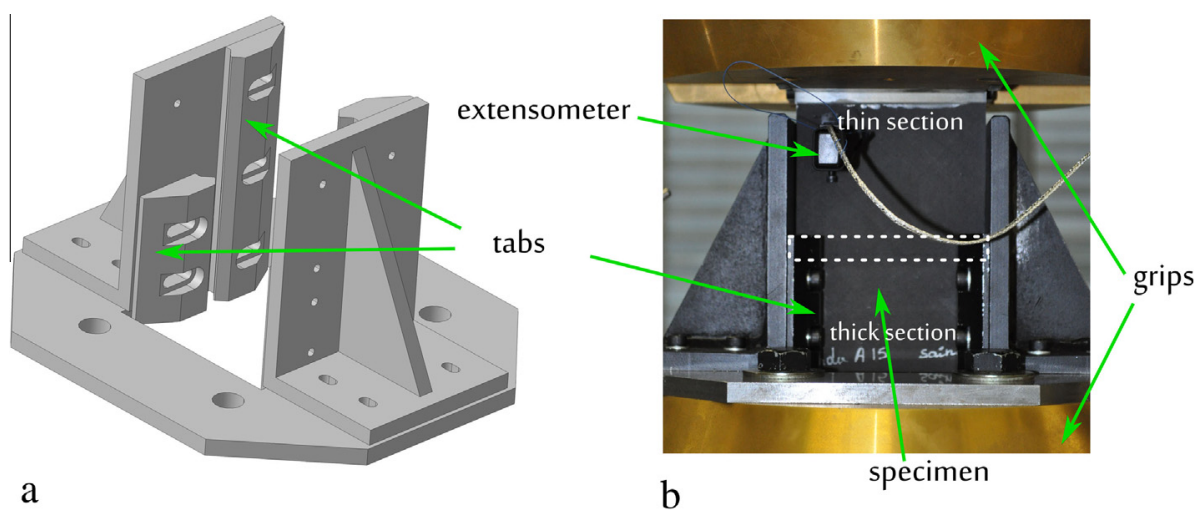

Fig. 3. CAI testing rig (a) manufactured parts, (b) photography of the test.

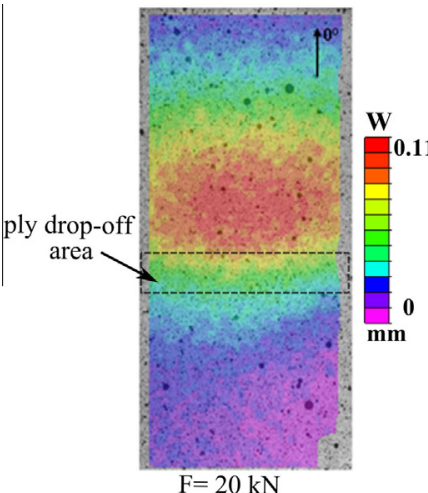

$\mathrm{F}=20 \mathrm{kN}$

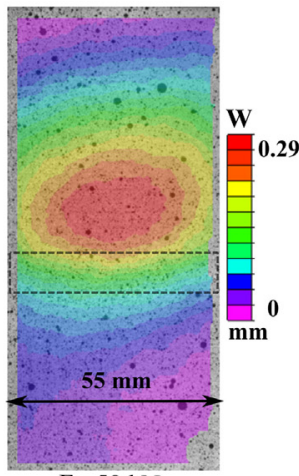

$\mathrm{F}=50 \mathrm{kN}$

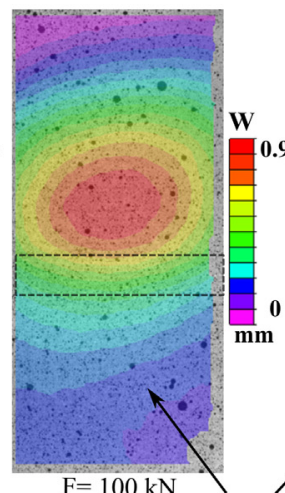

$\mathrm{F}=100 \mathrm{kN}$

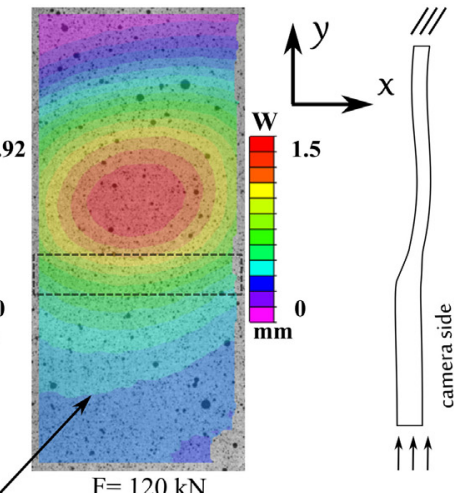

displacement induced by the lower grip

Fig. 4. Out-of-plane displacement field of $A_{15}^{\text {si }}$ pristine specimen. 


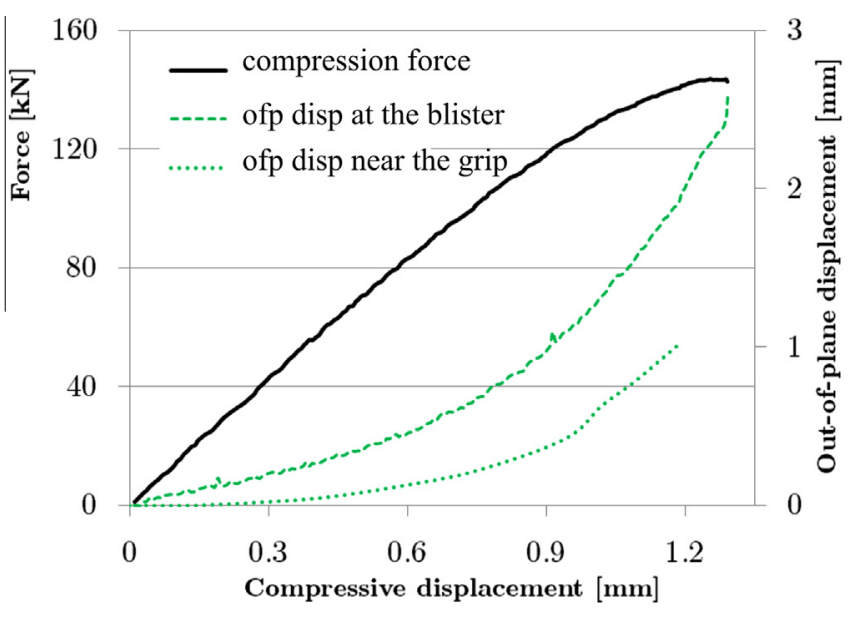

Fig. 5. Evolution of the compression force and out-of-plane (ofp) displacement curves of pristine $A_{15}^{\text {si }}$ specimen.

\section{Impact results}

This section provides a brief description of impact damage in order to introduce the analysis of CAI results presented in the following paragraphs. Fig. 6 shows the impact force-displacement curves of some A and B specimens. Note that detailed analysis of impact damage is available in [29]. The results show that the tests are quite reproducible. According to the force curves, the onset of important damage, essentially delamination, is at around $4 \mathrm{kN}$ for both types of specimens. A second loss of stiffness is observed for specimens impacted at $30 \mathrm{~J}$, which is associated to major fiber rupture inside the laminate.

The evolution of delamination with impact energy is presented in Fig. 7. The data is obtained from C-scan performed from the impacted face. Globally, delamination expansion evolves conically through the specimen thickness like in plain laminates. As the impact energy increases, larger propagation of delamination towards the transverse direction of the specimen is observed. At $30 \mathrm{~J}$ and for specimens A particularly, the delamination has reached
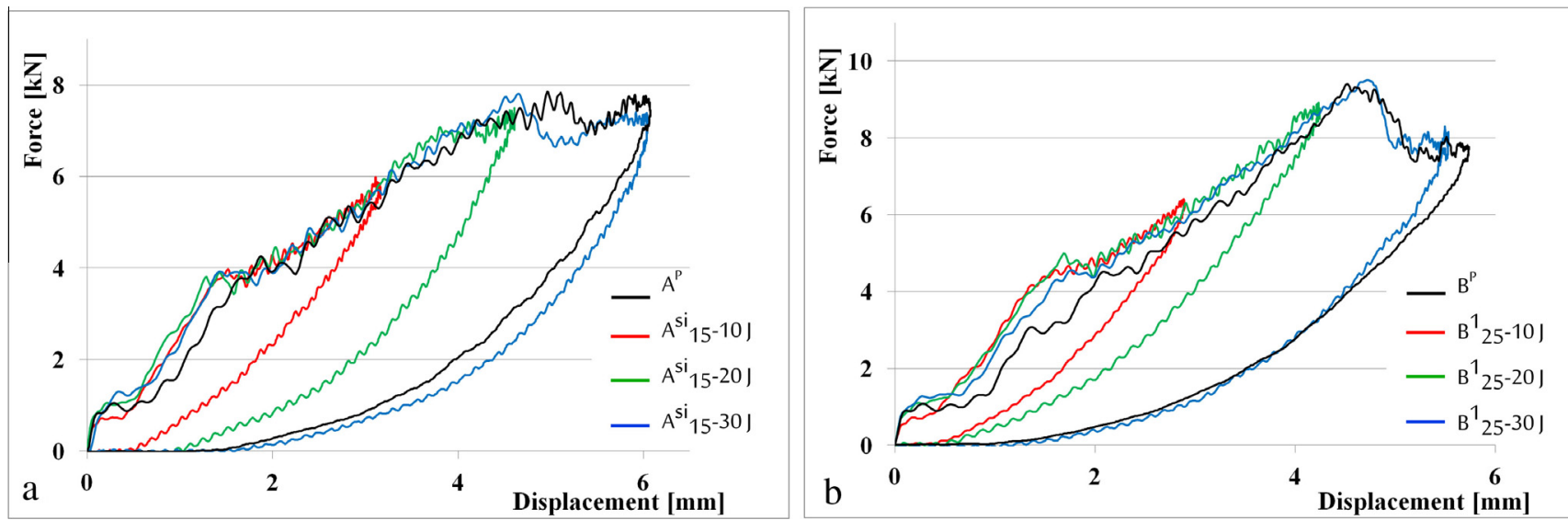

Fig. 6. Evolution of force-displacement curves for (a) A and (b) B specimens.

$10 \mathbf{J}$

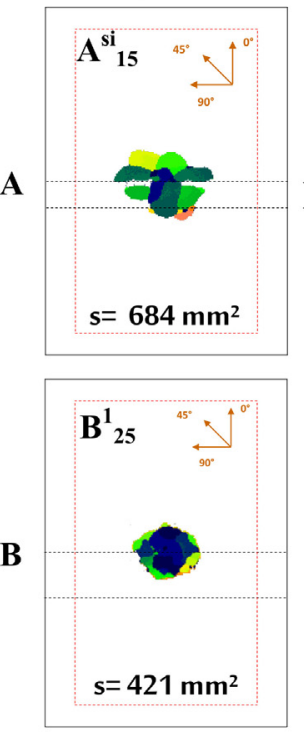

20 J
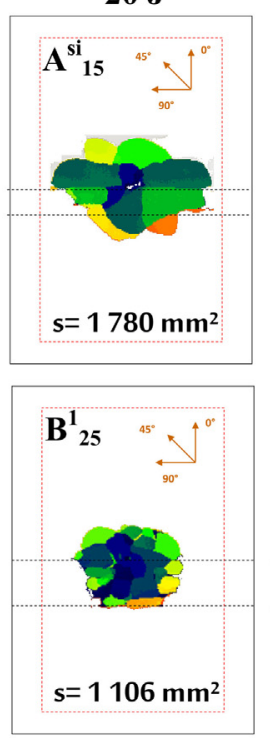

$30 \mathbf{J}$
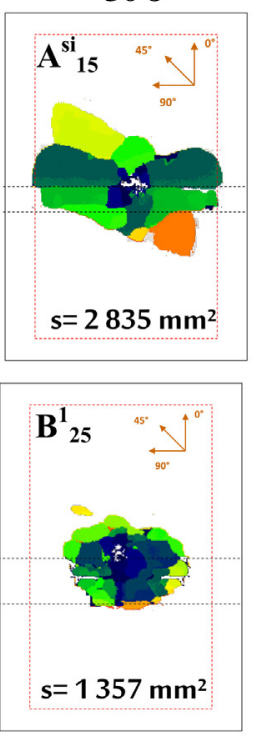

$30 \mathbf{J}$
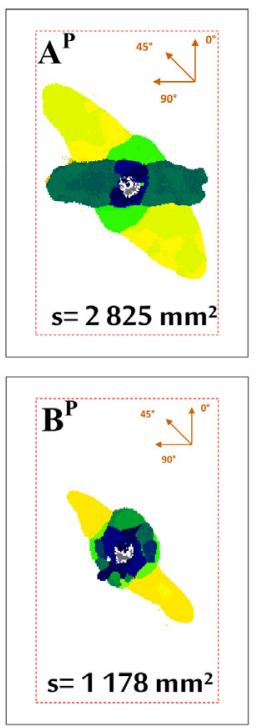

$0 \mathrm{~mm}$

\section{$50 \mathbf{~ m m}$}

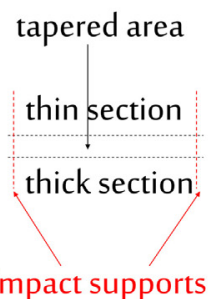

impact supports

Fig. 7. Evolution of delamination with impact energy for specimens A and B. 
the edges of the impact window. The size of delamination of type A specimens is larger compared to $B$ because type $B$ specimens have more inter-laminar interfaces, i.e. less projected area is required to dissipate the same amount of energy.

\section{CAI results comparison and analysis}

\subsection{Analysis of CAI curves}

Two specimens, $A_{15}^{\mathrm{si}}$ and $\mathrm{B}_{15}^{1}$, both impacted at $10 \mathrm{~J}$ will be considered for a detailed analysis of CAI behaviors. Fig. 8 shows their CAI force-displacement curves. Like in the case of pristine specimen, a non-linear behavior is observed after a certain load level for both cases. The non-linearity appears sooner in presence of damage: at $63 \mathrm{kN}$ for $\mathrm{A}_{15}^{\mathrm{si}}-10 \mathrm{~J}$ and at $80 \mathrm{kN}$ for $\mathrm{B}_{15}^{1}-10 \mathrm{~J}$. It results from both impact damage and small out-of-plane displacement of the grip ( $0.4 \mathrm{~mm}$ at failure load of both specimens). Note that the value of maximum out-of-plane displacement induced by the lower grip is even lower for specimens impacted at 20 and $30 \mathrm{~J}$ energy.

Some differences of behavior can be observed at the end of the tests between both specimens. For Specimen $A_{15}^{\text {si }}-10 \mathrm{~J}$ collapses while the failure is more progressive for $B_{15}^{1}-10 \mathrm{~J}$. For this last one, a saturation of the force is observed before failure which can be a sign of damage propagation. The use of acoustic emission would have been useful to associate the observed damage non-linearity to damage mechanism. When considering all the specimens tested in CAI, one of the two behaviors appears randomly and there is no favored failure mode observed.

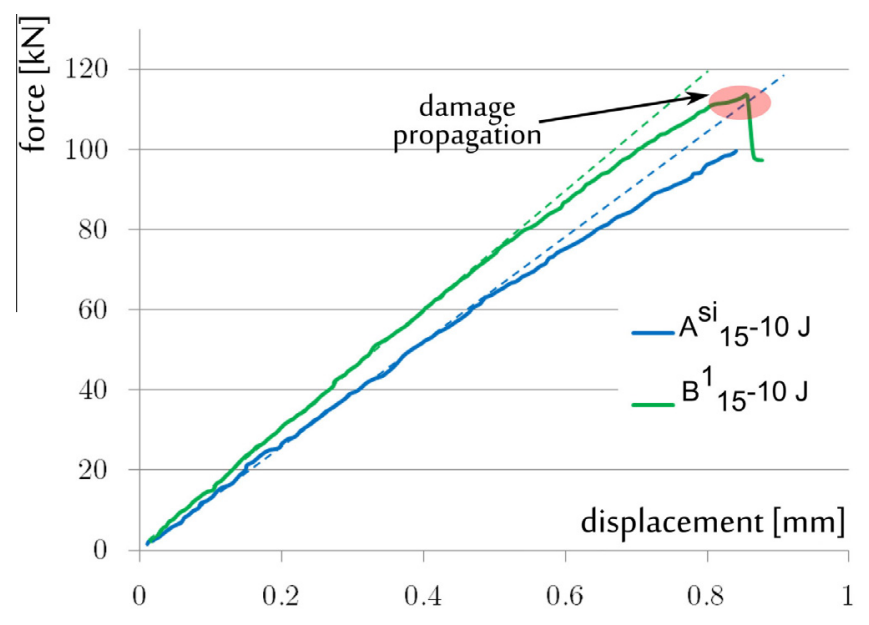

Fig. 8. Force-displacement curves in CAI.

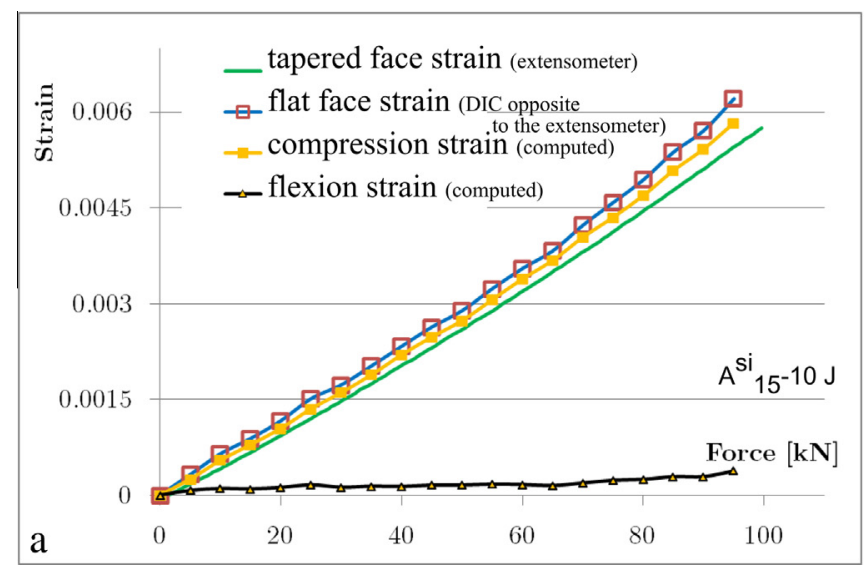

Fig. 9 shows the strains of the thin section, measured near specimen edge. The deformation of the flat side is from the extensometer and that of the tapered side is computed from DIC data. The strain from the DIC is averaged over a segment of $25 \mathrm{~mm}$ length to be equivalent with the strain from the extensometer. The residual compressive failure strain is about 0.006 for $\mathrm{A}_{15}^{\mathrm{si}}-10 \mathrm{~J}$ and 0.0052 for $B_{15}^{1}-10 \mathrm{~J}$. In spite of the blister of the thin section, the strains measured on both faces are quite close for specimens impacted at $10 \mathrm{~J}$; i.e. the laminate bending is reduced near the edges. Therefore, this area can be used to measure the residual compressive failure strain of impacted specimens. As the impact energy becomes higher, the contribution of bending increases and a strain difference of 0.002 can be reached between both sides of some specimens impacted at $30 \mathrm{~J}$ energy.

\subsection{CAI displacement field}

The displacement field of the specimens is presented in Fig. 10. For both tests, the isovalues of displacement in $y$-direction are horizontal indicating a homogenous loading along the specimen width. From the beginning of the test, a blistering is observed in thin section of the laminate. It is due to the bending generated by the discontinuity of neutral axis in the transition region. The deformed shape of the specimens is sketched in Fig. 11. Despite the local indentation created during impact, the blistering is oriented in the direction of the impacted face. In other words, the asymmetry of the ply drop-off takes over the impact indentation regarding the CAI response of the laminate. Moreover, both sides of the specimen are moving towards the same direction.

For specimen $A_{15}^{\mathrm{si}}-10 \mathrm{~J}$, the maximum out-of-plane displacement reaches $0.38 \mathrm{~mm}$ at $50 \mathrm{kN}$ and increases to $1.2 \mathrm{~mm}$ at $95 \mathrm{kN}$. Similar trend is observed for $\mathrm{B}_{15}^{1}-10 \mathrm{~J}$ specimen. However, a modification of its out-of-plane displacement field takes place as the force drops from its maximum value of $110 \mathrm{kN}$ to $98 \mathrm{kN}$. This loss of stiffness is accompanied by an expansion of the blister towards the transverse direction of the specimen. Note that despite this important change, the specimen still can sustain a great amount of load. This important observation confirms a propagation of damage prior to total collapse of specimen $B_{15}^{1}-10 \mathrm{~J}$. For both specimens, failure occurs at the level of the impacted area respectively at $100 \mathrm{kN}$ for $\mathrm{A}_{15}^{\mathrm{si}}-10 \mathrm{~J}$ and $112 \mathrm{kN}$ for $\mathrm{B}_{15}^{1}-10 \mathrm{~J}$ specimens.

\subsection{Effects of impact point location}

This paragraph analyses the effects of modifying the point of impact on the CAI results. As described in previous paragraphs, the behavior in CAI of tapered laminates is mainly characterized by the blistering of the thin section. The center of the blister is

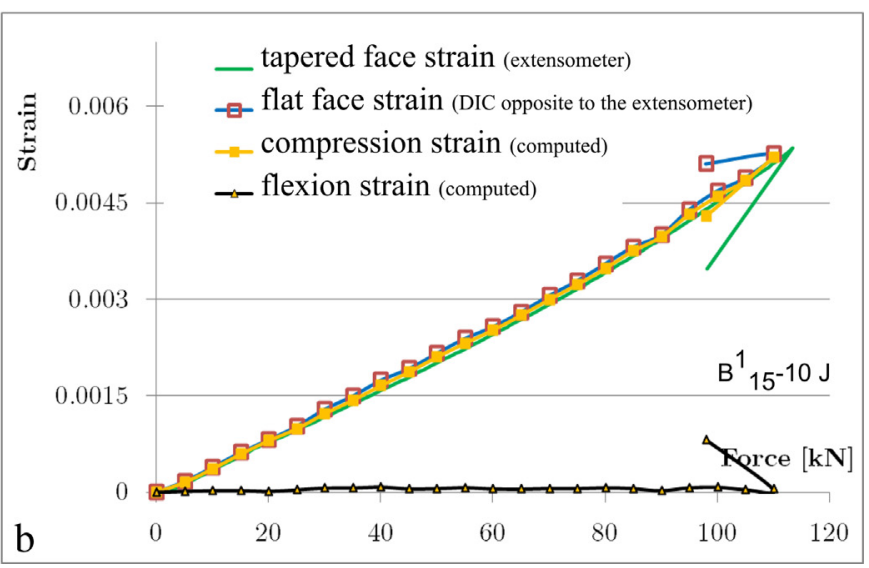

Fig. 9. Evolution of strain measured during CAI of (a) $A_{15}^{\mathrm{si}}-10 \mathrm{~J}$ and (b) $\mathrm{B}_{15}^{1}-10 \mathrm{~J}$ specimens. 


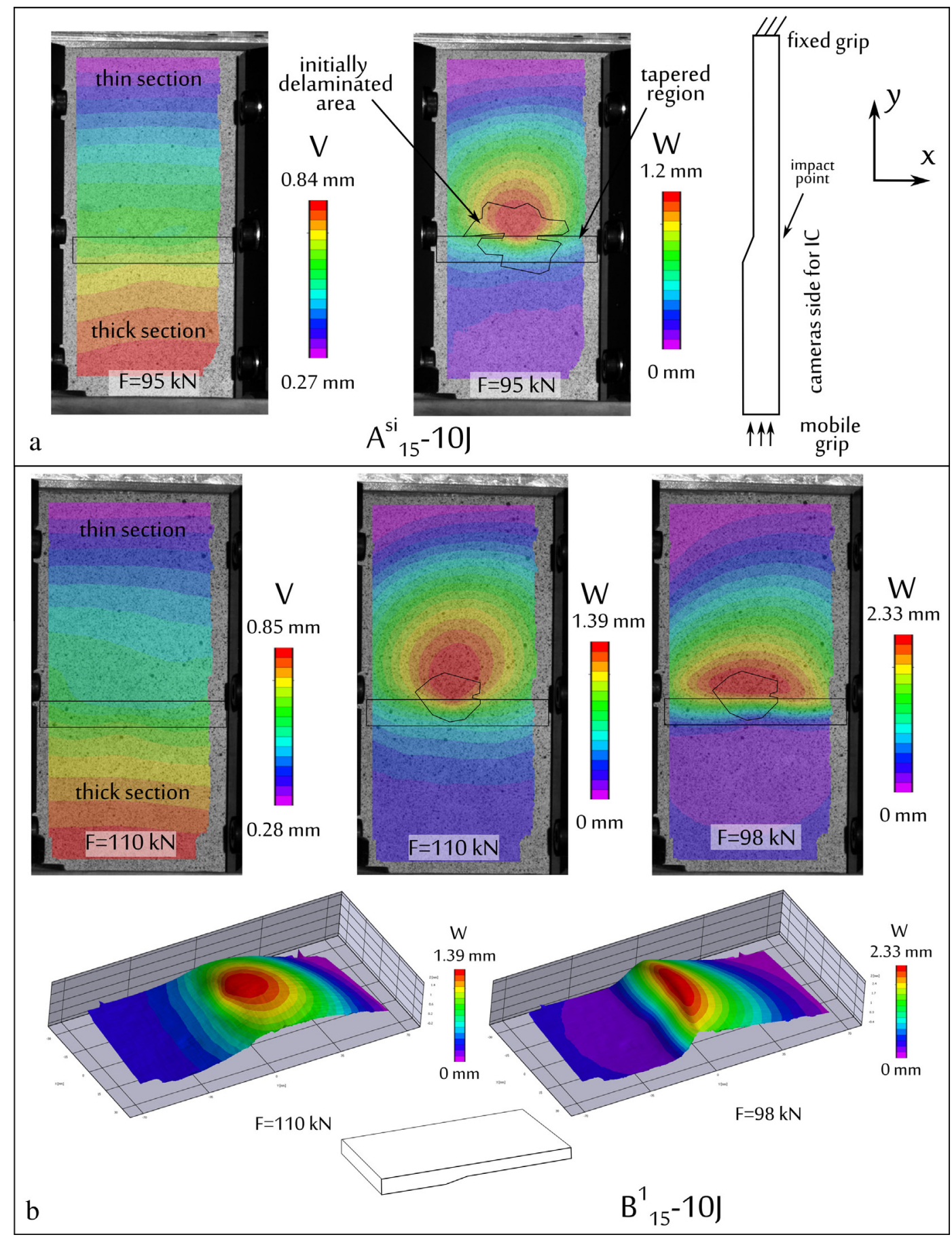

Fig. 10. Displacement field of (a) $A_{15}^{\mathrm{si}}-10 \mathrm{~J}$ and (b) $\mathrm{B}_{15}^{1}-10 \mathrm{~J}$ specimens.

located at $25 \mathrm{~mm}$ from the beginning of the tapered area. It is then interesting to interfere with the coupling between compression and bending by impacting at the center of the blister. The effects on the CAI results will be analyzed. For this purpose, $30 \mathrm{~J}$ impact tests on both sides of specimens $A_{15}^{\mathrm{si}}$ and $A_{25}^{\mathrm{si}}$ are performed with the same boundary condition. The specimens are named as $A^{\mathrm{si}}{ }_{x}-\mathrm{F}$ when the impact is performed on the flat face and $A^{\mathrm{si}}{ }_{x} \mathrm{~T}$ for an impact on the tapered side.

Fig. 12 presents the delamination after impact and the DIC data from CAI tests. Regarding the impact damage, the results show that an impact on the flat face (Fig. 12a) is more damageable. In such case, the bending of the laminate during impact tends to open inter-laminar interfaces of the tapered region promoting the propagation of delamination in the direction of the thick section. The opposite behavior is observed if the tapered face of the specimen is impacted (Fig. 12b).

Regarding the CAI, at the beginning of the test, both impact configurations behave similarly: a single blister due to bending is present in the thin section. Then, $A^{\text {si }}{ }_{x}$-T specimens keep the same shape until failure (Fig. 12b), however, $A^{\text {si }}{ }_{x}$-F specimens undergoes buckling characterized by two blisters (Fig. 12a) at around $60 \mathrm{kN}$. Note that this new shape is less supported by the boundary conditions since there is no support on the tapered side of the thin section (Figs. 2 and 11b). 


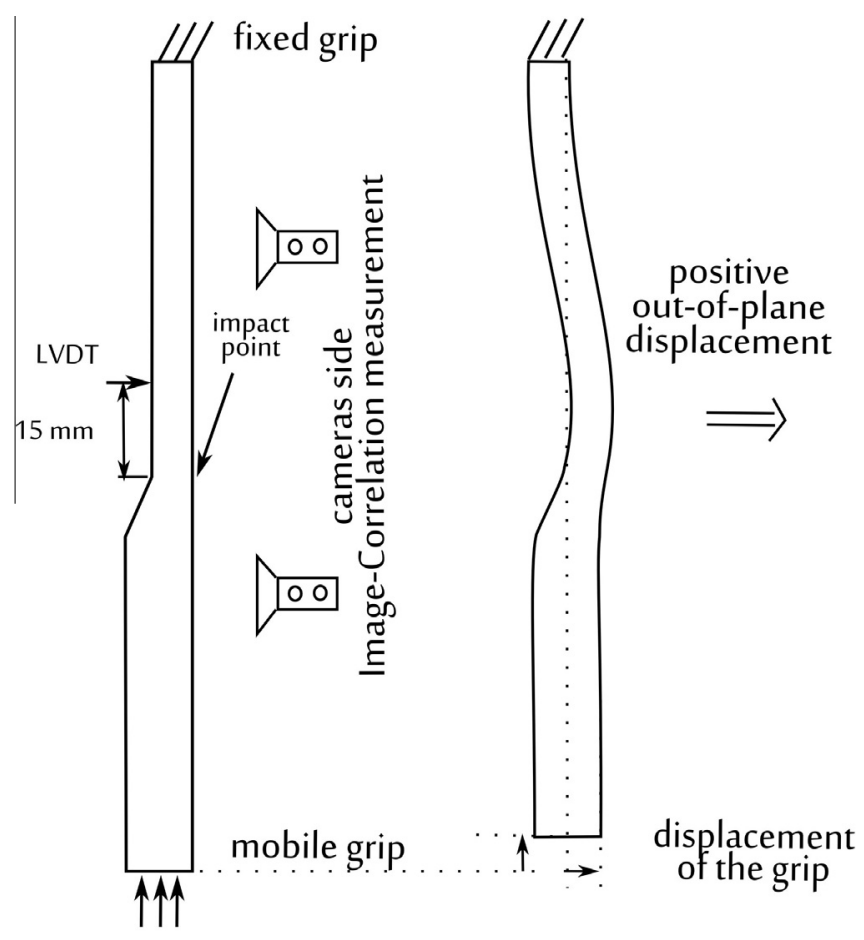

Initial state Deformed state
Fig. 13 compares the force-displacement curves of $A^{\mathrm{si}}{ }_{x}-\mathrm{F} / \mathrm{T}$ specimens with $A_{15}^{\text {si }}-30 \mathrm{~J}$. Although there is not any significant difference of the initial stiffness of the specimens, the residual strength is affected by the impact configuration. The failure strength of $A^{s i}$-T specimens $(70 \mathrm{kN})$ is comparable to that of $A_{15}^{\mathrm{si}}-30 \mathrm{~J}$ but it is lower, 61 and $68 \mathrm{kN}$ for $\mathrm{A}^{\mathrm{si}}{ }^{\mathrm{si}}$-F specimens. This variation of residual strength is directly related to the bending/buckling mode of the specimens as presented in Fig. 12. A premature failure occurs in the case of $\mathrm{A}^{\mathrm{si}}{ }_{x}-\mathrm{F}$ specimens since the buckling mode prior to failure is less supported by the boundary conditions. Although, the modification of impact point modifies impact damage and CAI behaviors of tapered laminate, the loss of residual failure strain observed with $\mathrm{A}_{x}^{\mathrm{si}}$-F can be mainly attributed to a limitation of the CAI testing rig.

\subsection{CAI failure mechanisms}

This paragraph aims at determining the CAI failure mechanism of tapered laminates. In the case of impact at the beginning of the tapered region, failure due to buckling is not possible since there is no real buckling observed. Previous observations raise naturally the question whether it is a propagation of delamination or fiber rupture in compression.

Fig. 14 compares the surface strain field in the load direction of $\mathrm{A}_{15}^{\mathrm{si}}-10 \mathrm{~J}$ and $\mathrm{B}_{15}^{1}-10 \mathrm{~J}$ tapered laminates with $\mathrm{A}^{\mathrm{P}}$ and $\mathrm{B}^{\mathrm{P}}$ flat laminates at $5 \mathrm{kN}$ before CAI failure load. The blistering of the thin section and the thickness variation induce an important variation of the surface strain. As opposed to flat laminate, there is no strain concentration at the impact area of tapered laminates. Due to the bending, the

Fig. 11. Sketching of the out-of-plane displacement.

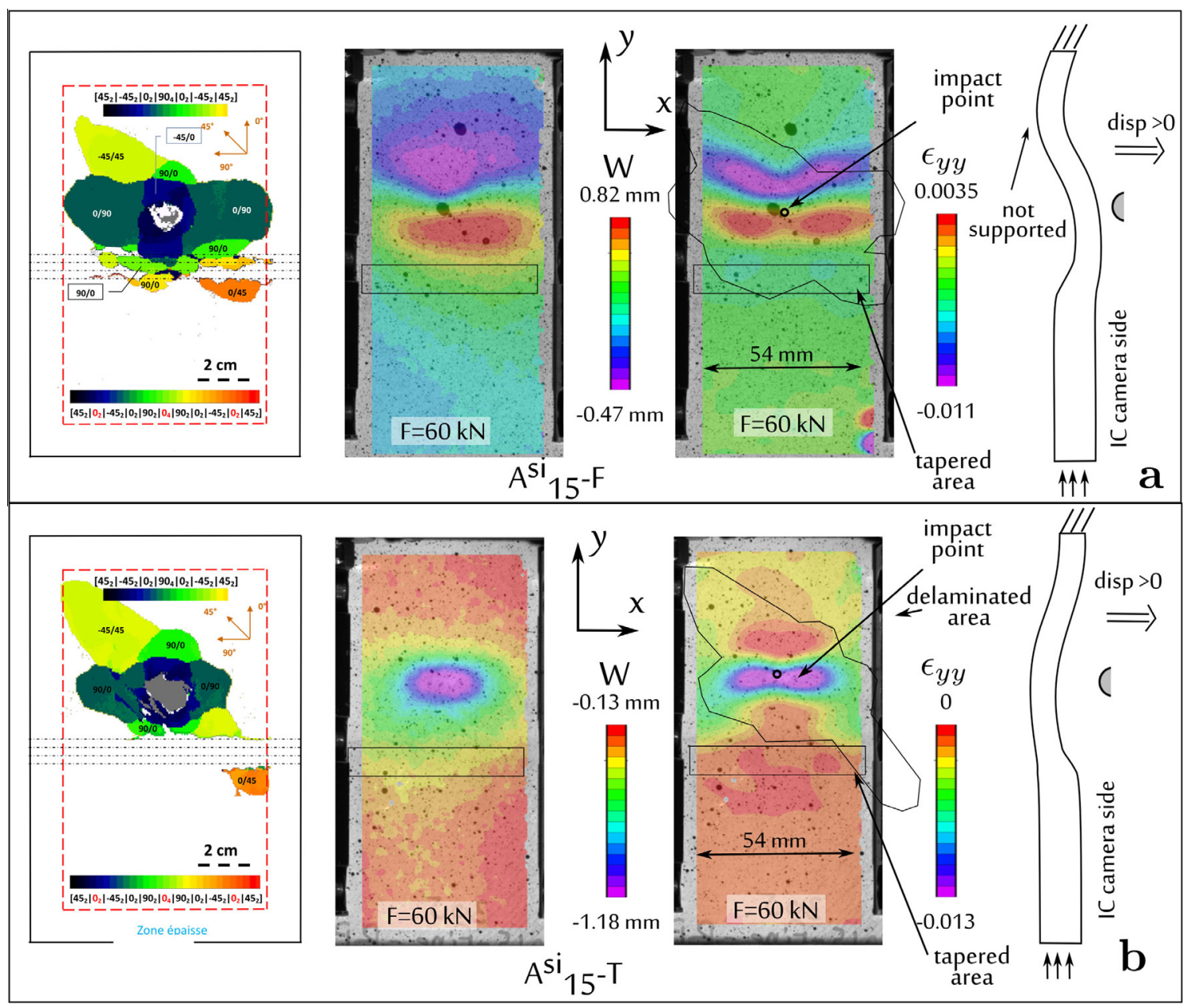

Fig. 12. Delamination and CAI behavior of $A_{15}^{s i}-F / T$ specimens. 


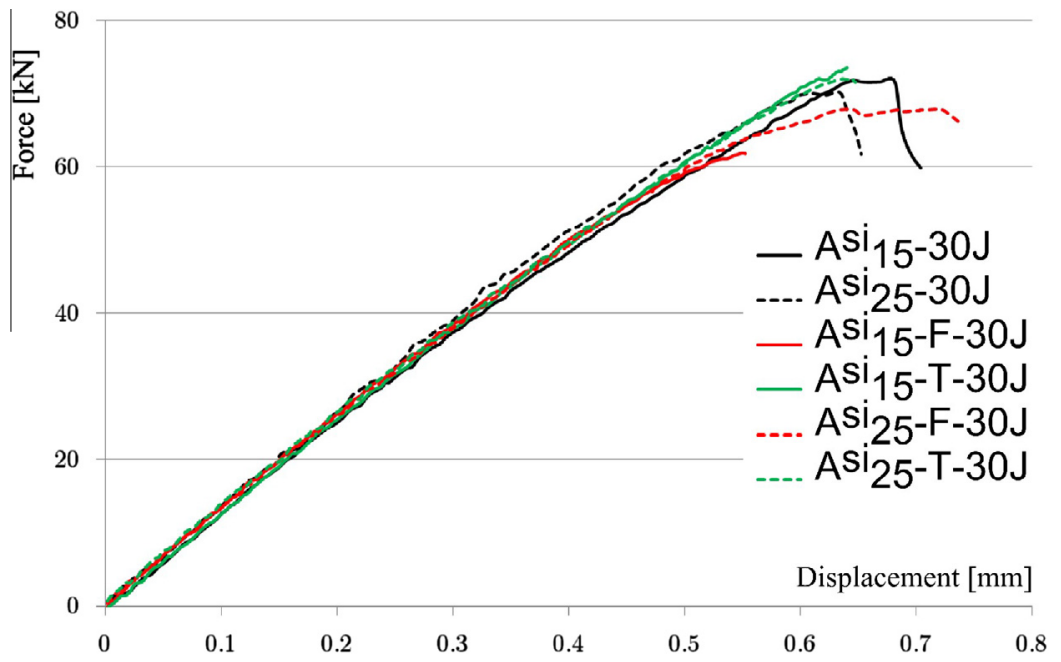

Fig. 13. Comparison of CAI force-displacement curves of $A_{x^{-}}^{\mathrm{si}}-\mathrm{T} / \mathrm{F}$ with $\mathrm{A}^{\mathrm{si}}{ }_{x}-30 \mathrm{~J}$ specimens.

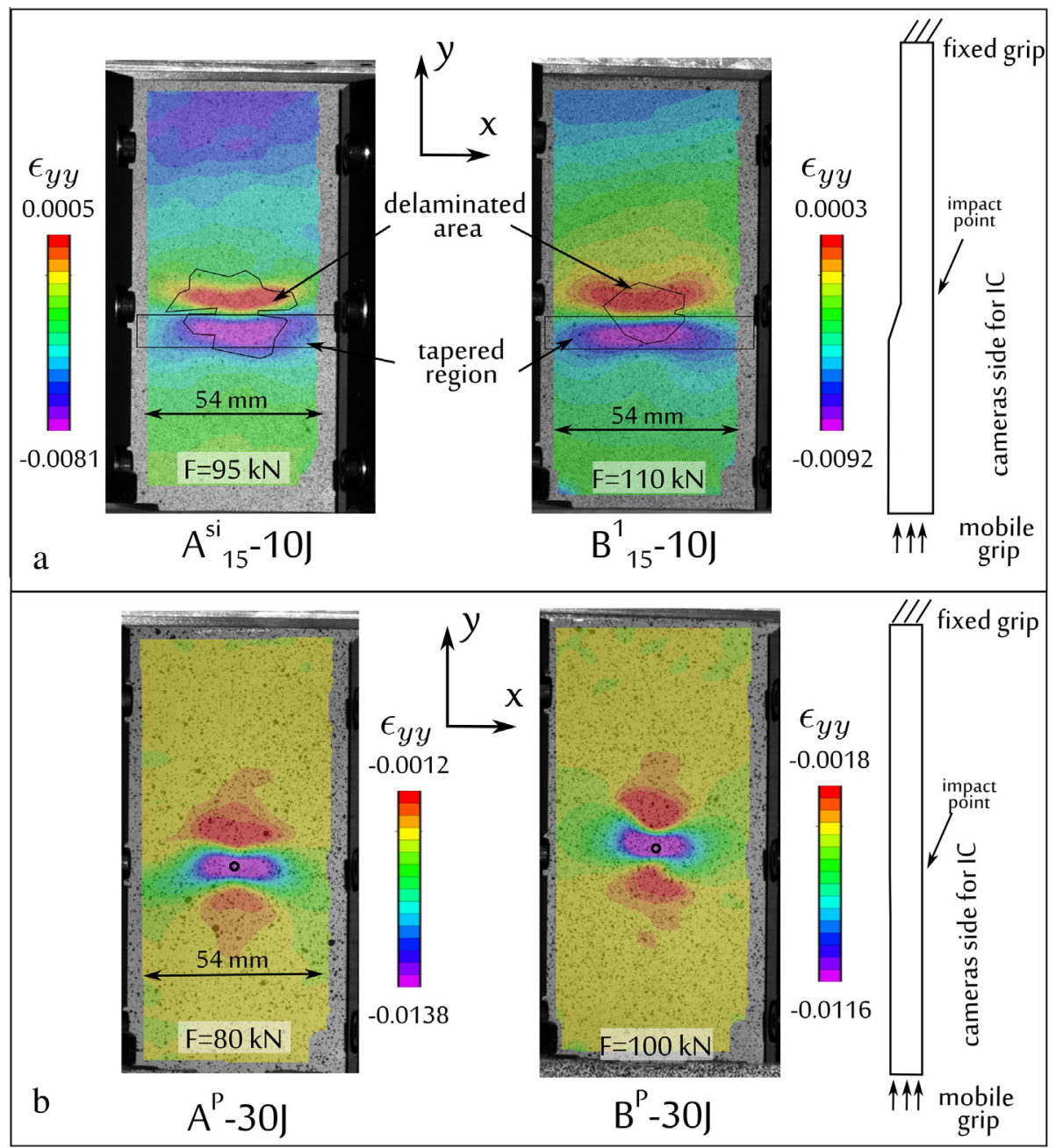

Fig. 14. Surface strains measured from IC system (a) tapered laminates and (b) flat laminates.

longitudinal strain is almost positive at the beginning of the thin section and a high compressive strain is observed in the transition region. Nevertheless, since external ply is oriented at $45^{\circ}$, surface strain field is not relevant to decide on the possibility of failure due to propagation of fiber failure in compression. Therefore, the deformation of $0^{\circ}$ continuous ply before specimen failure needs to be known.

Such information is not directly available from the experiment but can be computed from the surface strain and curvature provided by the IC. Assuming a Mindlin plate theory, the deformation 
of a given internal ply is computed with equation (Eq. (1)). Note that, this method assumes a continuous strain through the specimen thickness which is not fully satisfied in the delaminated area.

$\epsilon_{x x}(z)=\epsilon_{x x}\left(z_{e x t}\right)-\left(z-z_{e x t}\right) * \frac{\partial^{2} w}{\partial x^{2}}\left(z_{e x t}\right)$

Fig. 15 shows the deformation computed at mid-thickness of some $0^{\circ}$ continuous plies of both specimens $A_{15}^{\text {si }}-10 \mathrm{~J}$ and $\mathrm{B}_{15}^{1}-10 \mathrm{~J}$. Only the area of the thin section is presented. In both cases, the ply nearest to the tapered side reaches the material compressive failure strain in fiber direction -0.0125 .

Although the computed results cannot be fully trusted because of delamination, specimen failure by propagation of fiber rupture in compression cannot be excluded. On the other hand, progressive failure characterized by a major modification of surface curvature $\left(\mathrm{B}_{15}^{1}-10 \mathrm{~J}\right)$ can only be explained by a propagation of delamination. The newly delaminated sub-laminate would then undergo localbuckling as observed in Fig. 10.

In summary, the analysis of experimental data does not allow to determine accurately the failure mechanisms in CAI. It is possible that fiber failure occurs in both cases according to the deformation of internal plies. As it was reported by some authors [17,30], such propagation of fiber failure can be stable or not depending on the test. Both phenomena may happen with the tapered specimen. An unstable propagation of fiber rupture would result in a collapse of the specimen. However, in the case of stable propagation, there is time for delamination to grow which induces some local buckling as observed externally in the case of specimen $B_{15}^{1}-10 \mathrm{~J}$ (Fig. 10). Therefore, delamination and fiber failure in compression are then highly interlinked.

\subsection{Damage tolerance of tapered laminates}

The evaluation of damage tolerance is important for designer. In this paragraph, the residual strength of all tested specimens is presented. The results are also compared with data of flat laminates tested with the same boundary condition (clamped edges and longitudinal buckling supports on both faces). Moreover, for $\mathrm{A}^{\mathrm{P}}$ specimens, some results from Hongkarnjanakul [31] with the same material but using Airbus standard AITM1-0010 boundary conditions are also presented. Results are compared in terms of compressive strain to be transposable between layups. For tapered laminates, the compressive strain is computed as the mean between the strain obtained from the DIC and the extensometer. The material failure strain in compression in the fiber direction -0.0125 is arbitrary considered for pristine specimens.

Fig. 16 shows the evolution of failure strain in function of impact energy for A and B specimens. For both layups, an important loss of resistance is observed compared to the material initial strength. At $10 \mathrm{~J}$, the residual strength is already less than $50 \%$. Between $10 \mathrm{~J}$ and $30 \mathrm{~J}$, another $10 \%$ loss is found. Statistically, the residual strength of type $B$ specimens is slightly higher than $\mathrm{A}$. For example, at $30 \mathrm{~J}$, the mean failure deformation is -0.0036 for $A$ and -0.0047 for $B$. Interestingly; the influence of ply drop-off parameters (slope, configuration) is limited. The variation is between $5 \%$ and $10 \%$ between the different configurations of the specimens tested. Even though there are not enough tests to evaluate the scattering of the results, the variation due to ply drop-off parameters remains small. Moreover, the Fig. 16 shows that residual strength in CAI of tapered laminates is similar to that of flat laminates for both A and B layups. Indeed, even if a slightly lower value of the residual strength is found for

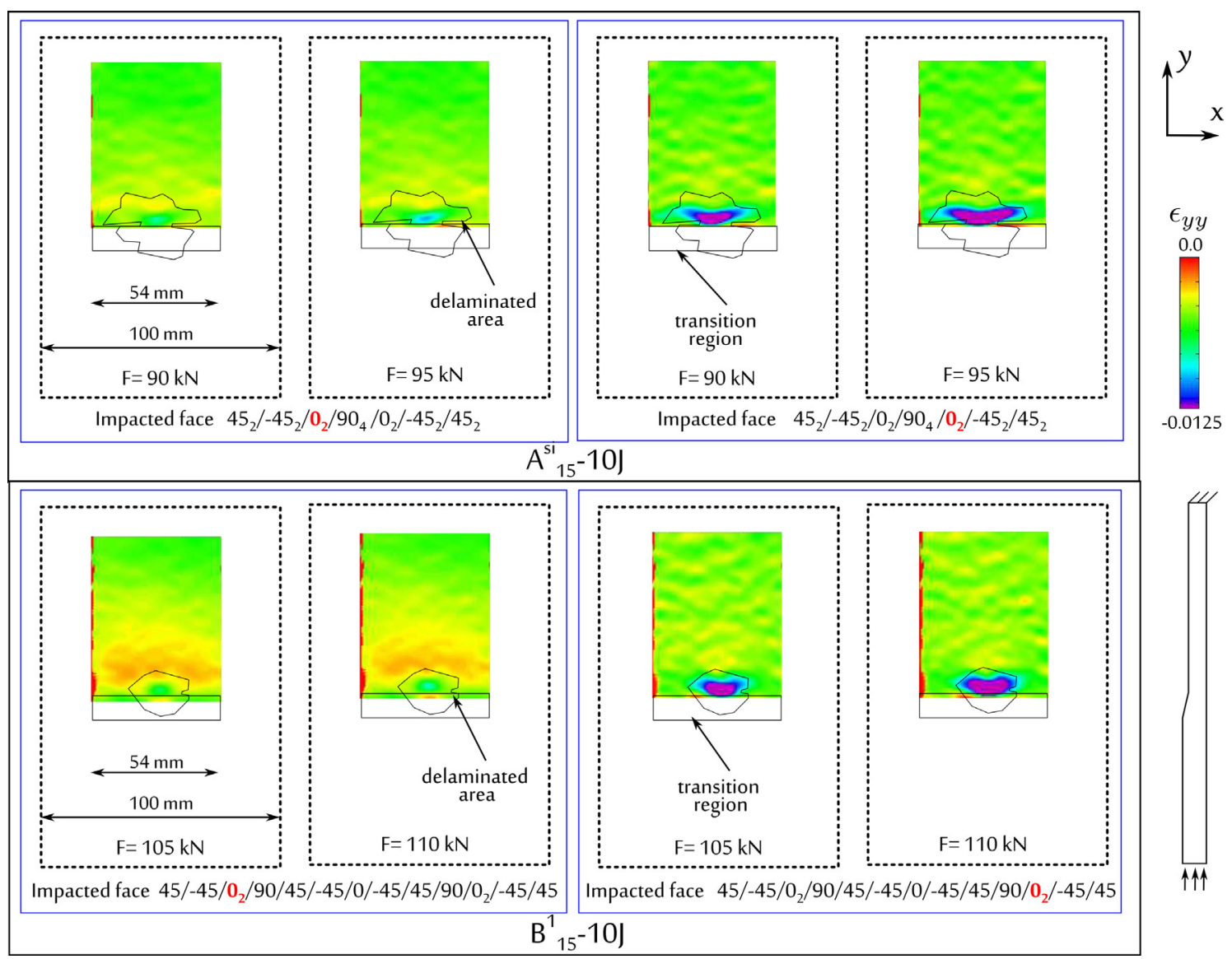

Fig. 15. Computed strain of internal $0^{\circ}$ plies before specimens failure. 


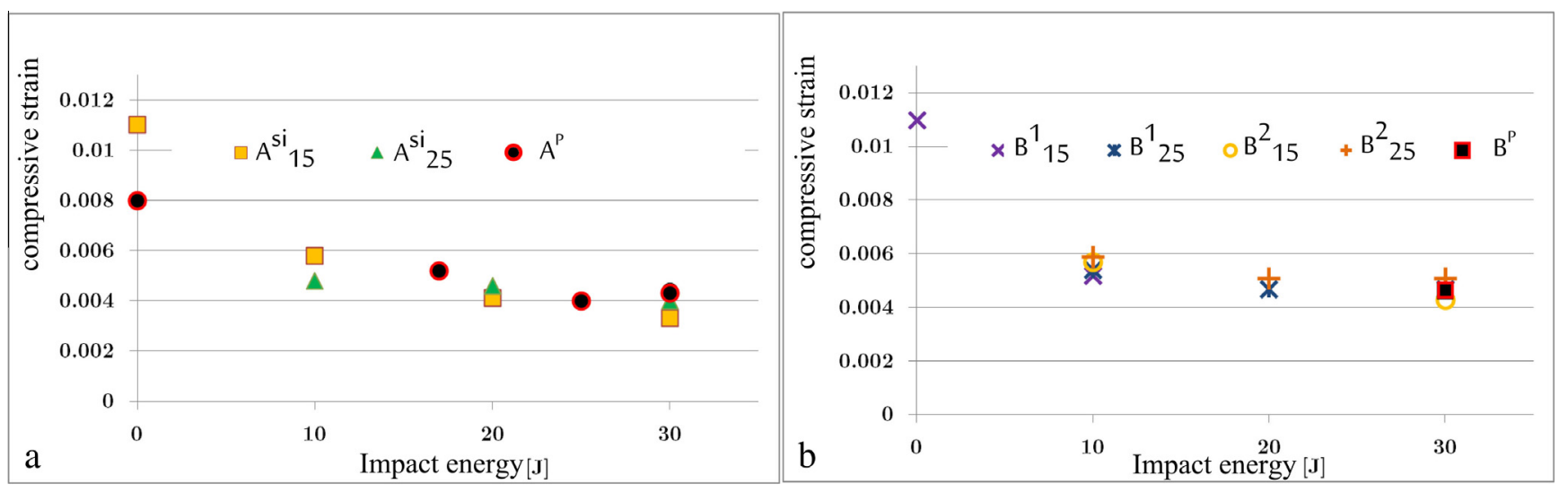

Fig. 16. Evolution of CAI failure strain of (a) A and (b) B specimens.

the asymmetrically tapered laminate $A_{15}^{\text {si }}$ compared to the flat panel (Fig. 16), this small difference is not considered significant regarding the important scattering of the CAI tests (even if more experimental results are necessary to confirm this result). Such information is important for designers of composite structure. It shows that there is no need for specific experimental evaluation of CAI strength of tapered laminates.

\section{Conclusion}

This paper has presented a detailed analysis of CAI behavior of asymmetrically tapered laminates. For this purpose, new CAI boundary conditions were defined to reproduce at the level of the specimen the response of a stiffened panel with such type of tapering. Therefore, a new testing rig has been designed and validated for test.

Experimental tests highlighted that CAI response of tapered laminates is governed by the coupling between compression and bending behaviors. A blister oriented in opposite to impact indentation is observed in the thin section from the beginning of the test and there is no real buckling of the laminate until failure. The failure mechanisms are complex to identify. Delamination and fiber failure are highly intricate. The proposed scenarios consist in an initial propagation of fiber rupture. Then, depending on its stability, the specimen may collapse or there may be some progressive damage propagation like delamination. However, some additional investigations are required to verify such scenarios. Regarding the residual strength, the study of layups A and B shows that there is not any significant loss of strength related to the tapering. Tapered laminates have similar damage tolerance compared to flat laminates. Moreover, the variation of the parameters of the ply drop-off has limited effect on the CAI strength. From a design point of view, it may not be required to realize a specific study of damage tolerance of tapered laminates. Anyway, it should be noted that the study focuses on a specific type of tapered laminates under uniaxial loading. In perspective, it would be interesting to pursue this investigation on a larger test campaign and under more complex loads especially multiaxial ones. Also, the fatigue behavior of impacted tapered laminates is of great interest and this study will be pursued on this subject.

\section{Acknowledgement}

The authors gratefully acknowledge SOGETI HIGH TECH for the financial support of this Ph.D. program.

\section{References}

[1] Abrate S. Impact on composite structures. Cambridge University Press; 2005.

[2] Cantwell W, Morton J. The impact resistance of composite materials - a review. Composites 1991;22:347-62. http://dx.doi.org/10.1016/0010-4361 (91) $90549-\mathrm{V}$.

[3] Irving PE, Cartie DDR. Effect of resin and fibre properties on impact and compression after impact performance of CFRP. Compos Part A Appl Sci Manuf 2002;33:483-93.

[4] Ishikawa T, Sugimoto S, Matsushima M, Hayashi Y. Some experimental findings in compression-after-impact (CAI) tests of CF/PEEK (APC-2) and conventional CF/epoxy flat plates. Compos Sci Technol 1995;55:349-63. http://dx.doi.org/10.1016/0266-3538(95)00079-8.

[5] Lopes CS, Camanho PP, Gürdal Z, Maimí P, González EV. Low-velocity impact damage on dispersed stacking sequence laminates. Part II: numerical simulations. Compos Sci Technol 2009;69:937-47. http://dx.doi.org/10.1016 i.compscitech.2009.02.015.

[6] Hongkarnjanakul N, Bouvet C, Rivallant S. Validation of low velocity impact modelling on different stacking sequences of CFRP laminates and influence of fibre failure. Compos Struct 2013;106:549-59. http://dx.doi.org/10.1016/ i.compstruct.2013.07.008.

[7] Aymerich F, Priolo P. Characterization of fracture modes in stitched and unstitched cross-ply laminates subjected to low-velocity impact and compression after impact loading. Int J Impact Eng 2008;35:591-608. http:// dx.doi.org/10.1016/i.ijimpeng.2007.02.009.

[8] Tan KT, Yoshimura A, Watanabe N, Iwahori Y, Ishikawa T. Effect of stitch density and stitch thread thickness on damage progression and failure characteristics of stitched composites under out-of-plane loading. Compos Sci Technol 2013;74:194-204. http://dx.doi.org/10.1016/i.compscitech. 2012.11.001.

[9] Zhang X, Hounslow L, Grassi M. Improvement of low-velocity impact and compression-after-impact performance by z-fibre pinning. Compos Sci Technol 2006;66:2785-94. http://dx.doi.org/10.1016/i.compscitech.2006.02. $\underline{029}$.

[10] Petit S, Bouvet C, Bergerot A, Barrau J-J. Impact and compression after impact experimental study of a composite laminate with a cork thermal shield. Compos Sci Technol 2007;67:3286-99. http://dx.doi.org/10.1016 i.compscitech.2007.03.032

[11] Habib FA. A new method for evaluating the residual compression strength of composites after impact. Compos Struct 2001;53:309-16. http://dx.doi.org/ 10.1016/S0263-8223(01)00015-0.

[12] Sanchez-Saez S, Barbero E, Zaera R, Navarro C. Compression after impact of thin composite laminates. Compos Sci Technol 2005;65:1911-9. http://dx.doi. org/10.1016/j.compscitech.2005.04.009.

[13] Bull DJ, Spearing SM, Sinclair I. Observations of damage development from compression-after-impact experiments using ex situ micro-focus computed tomography. Compos Sci Technol 2014;97:106-14. http://dx.doi.org/10.1016 i.compscitech.2014.04.008.

[14] De Freitas M, Reis L. Failure mechanisms on composite specimens subjected to compression after impact. Compos Struct 1998;42:365-73.

[15] Berketis K, Tzetzis D, Hogg PJ. The influence of long term water immersion ageing on impact damage behaviour and residual compression strength of glass fibre reinforced polymer (GFRP). Mater Des 2008;29:1300-10. http://dx. doi.org/10.1016/i.matdes.2007.07.008.

[16] Ghelli D, Minak G. Low velocity impact and compression after impact tests on thin carbon/epoxy laminates. Compos Part B Eng 2011;42:2067-79. http://dx. doi.org/10.1016/i.compositesb.2011.04.017.

[17] Rivallant S, Bouvet C, Abi Abdallah E, Broll B, Barrau J-J. Experimental analysis of CFRP laminates subjected to compression after impact: the role of 
impact-induced cracks in failure. Compos Struct 2014;111:147-57. http://dx doi.org/10.1016/i.compstruct.2013.12.012.

[18] Xing YM, Yun H, Dai FL. An experimental study of failure mechanisms in laminates with dropped plies. Compos Sci Technol 1999;59:1527-31. http:/ dx.doi.org/10.1016/S0266-3538(99)00003-2.

[19] Steeves CA, Fleck NA. Compressive strength of composite laminates with terminated internal plies. Compos Part A Appl Sci Manuf 2005;36:798-805 http://dx.doi.org/10.1016/j.compositesa.2004.10.024.

[20] Murri G. Testing and life prediction for composite rotor hub flexbeams. Int J Fatigue 2006;28:1124-35. http://dx.doi.org/10.1016/i.iifatigue.2006.02.029.

[21] Wisnom MR, Jones MI, Cui W. Failure of tapered composites under static and fatigue tension loading. AIAA J 1995;33:911-8. http://dx.doi.org/10.2514/ 3.12510 .

[22] Weiss A, Trabelsi W, Michel L, Barrau JJ, Mahdi S. Influence of ply-drop location on the fatigue behaviour of tapered composites laminates. Proc Eng 2010;2:1105-14. http://dx.doi.org/10.1016/i.proeng.2010.03.119.

[23] Greenhalgh E, Bishop SM, Bray D, Hughes D, Lahiff S, Millson B. Characterisation of impact damage in skin- stringer composite structures. Compos Struct 1996;36:187-207.
[24] Kairouz KC, Ball J. Impact of ply drops. Beijing, China: ICCM; 2001.

[25] Boeing. Advanced composite compression tests. Seattle, Washington; 1988.

[26] Airbus Industrie Test Method. Fiber Reinforced plastics determination of compression strength after impact, AITM-1.0010, Issue 2. Blagnac; 1994.

[27] ASTM. Standard Test Method for Measuring the Damage Resistance of a FiberReinforced Polymer Matrix Composite to a Drop-Weight Impact Event. ASTM Stand 2007. http://dx.doi.org/10.1520/D7136.

[28] ASTM. Standard Test Method for Compressive Residual Strength Properties of Damaged Polymer Matrix Composite Plates. ASTM Stand 2006.

[29] Abdulhamid H, Bouvet C, Michel L, Aboissière J, Minot C. Influence of internally dropped-off plies on the impact damage of asymmetrically tapered laminated CFRP. Compos Part A Appl Sci Manuf 2015;68:110-20. http://dx.doi.org/ 10.1016/i.compositesa.2014.09.024.

[30] Kinsey A, Saunders DEJ, Soutis C. Post-impact compressive behaviour of low temperature curing woven CFRP laminates. Composites 1995;26:661-7. http://dx.doi.org/10.1016/0010-4361(95)98915-8.

[31] Hongkarnjanakul N. Modélisation numérique pour la tolérance aux dommages d'impact sur stratifié composite: De l'impact à la resistance résiduelle en compression. thèse de l'Université de Toulouse; 2013. 